\title{
The Role of Centralization of Power in Combatting Pandemics
}

\author{
Param Patel $^{1}$ and Jay Sandesara ${ }^{1}$ \\ 1SATEK@W.A. Porter Collegiate Institute, Ontario, Canada
}

\section{ABSTRACT}

Advancements in technology have enabled humanity to be more interconnected than ever, strengthening our economies and promoting globalization. However, as seen in the 2020 Coronavirus Pandemic, such a high degree of interconnectedness between nations and peoples allows infectious diseases to spread around the world at unprecedented rates. We have seen hundreds of nations attempt to combat the COVID-19 Pandemic in many different ways with varying amounts of success, from total isolation and quarantine to attempting to procure herd immunity through exposure. The People's Republic of China, being the first nation to deal with the coronavirus pandemic set a new standard for disease identification, control and eradication by eliminating the disease completely within a matter of months. Method: This paper analyzes the coronavirus strategies of three major nations, China, South Korea, and the United States, by comparing the severity and types of measures taken to contain/prevent spread to the efficacy of those measures as seen in their respective curves. Results: From the analysis, it was clearly seen that having a high degree of power centralization with respect to the federal government as seen in China and South Korea along with minimal opposition from individual states, parties, and the legal system allowed for vastly more effective pandemic control as compared to libertarian nations with higher levels of autonomy for both lower levels of government and individuals such as what is seen in the United States of America.

\section{Introduction}

Countries with high centralization of power and/or the ability to impose severe restrictions in times of need without due interference are more effective in controlling the spread of disease within their borders than countries with government systems that restrict their ability to impose the restrictions necessary to curb the spread of disease for both legislative and/or ideological reasons. This paper is not intended to rank libertarian governments versus authoritarian governments, but rather to compare the effects of government ideology and the corresponding severity of restrictions on disease control. This paper will examine the COVID-19 epidemic in three major countries, the United States, China, and South Korea. The purpose of this research paper is to outline and analyze examples of epidemic control in various countries with differing forms of government and identify the system or systems that show the greatest efficacy in outbreak prevention and mitigation.

\section{COVID-19 Epidemic in the People's Republic of China}

"The early responses and measures adopted by China, such as early reporting and situation monitoring, large-scale surveillance, and preparation of medical facilities and supplies, were all successful in reducing the epidemic in China generally and in the epicenter of Wuhan specifically." (AlTakarli, 2020). Although China has a population of 1.38 billion people, it has only 85,320 confirmed reported cases, and 4,648 confirmed reported deaths (World Health Organization, 2020). 


\section{Fast Mobilization and Availability of Vital Resources}

Being an authoritarian, Communist country, the Chinese government had unprecedented power to sequester and direct all necessary resources and workforces to the construction of temporary care facilities in Hubei province to provide healthcare for the increasing number of patients. In early February, the Chinese government constructed and opened 2 hospitals in Wuhan in a record time of ten days to provide 2600 extra beds for COVID-19 patients (Miller, 2020). Furthermore, although a highly controversial move, and one that infringes on the fundamental rights of operating businesses, the Chinese government used its wide powers to nationalize all major N95 mask producers in China, effectively banning exports of the vital PPE product, and redirecting all production towards use in Chinese hospitals (Rapoza, 2020). This move ensured that all Chinese hospitals had access to N95 masks (which can prevent the spread of COVID-19 between individuals) and thus played a key role in disease containment within the country.

\section{Mass Surveillance and Subsequent Punishment}

Data suggests that to contain spread in early stages in a scenario like the one presented in China, about $70 \%$ of the contacts of an infected person would need to be successfully traced and tested (Anderson et al., 2020). The only known effective way to do so is by taking advantage of the smartphone technology that almost all citizens carry. The Chinese government quickly introduced a QR Code based system that assigned each citizen a phone based QR code that could be Red, Yellow, or Green, based on the health questionnaire filled out by a person. These QR codes would need to be produced at checkpoints to show that a person possessed a green QR code (not a risk) rather than a Yellow QR code (supposed to be in 7-day quarantine) or a Red one (supposed to be in a 14-day quarantine). This would allow officials to find those who were violating their quarantine and prevent them from free passage of the city. Furthermore, the government could also keep track of people who enter and leave a city be mandating that the drivers must scan a QR code carried by a drone, thus registering their movements in a database (The Economist, 2020). The government promised strict punishments for those who violated their quarantines with threats as severe as the death penalty. (Dewan et al., 2020). Although harsh, and perhaps even violating what the West sees as basic human rights and privacy, these measures allowed the government to keep track of all infected patients and prevent them from spreading their disease to others.

\section{COVID-19 Epidemic in the Republic of Korea (South Korea)}

The Republic of Korea has reported only 13, 137 cases of the novel coronavirus and 284 associated deaths. (World Health Organization, 2020). Although a democracy with ideals similar to the West, the South Korean government was able to impose strict restrictions without facing any criticism or legal/constitutional interference. The country managed to flatten the curve even without imposing restrictions as strict as China.

\section{Discriminatory Testing and Mandatory Inspection}

The $31^{\text {st }}$ recorded Coronavirus patient in South Korea, "a 61-year-old woman, became the first congregant of the Shincheonji Church of Jesus in Daegu to test positive. It was unclear where she contracted the virus." (Shin et al., 2020). The country's biggest cluster of infections later emerged among the Daegu congregation and the church accounted for more than half of South Korea's total infections, however, they refused to cooperate with investigations and were fixed on keeping their followers identities secret. The South Korean government refused to give higher importance to protecting the rights of one group of people at the cost of the lives of thousands of others and proceeded to order the church to hand over its list of followers, to which they complied (McKenna, 2020). They government then ordered the compulsory testing of more than 200,000 members of the church, with thousands testing positive. Moreover, the government also mandated the inspection of all high-risk gathering paces regardless of whether they were private businesses (Shin et al., 2020). This trade off between the society-debilitating rights of a few citizens for the 
lives of millions of others can be seen as an important factor that lead to South Korea's rapid, and highly effective containment of the Coronavirus disease; the rate of new infections slowed from 909 cases/day on Feb.29 to 100 or less since mid-March (Shin et al., 2020)

\section{Mass Tracking/Surveillance}

The South Korean government mandated that "all inbound passengers have to download a cellphone app that allows the government to monitor them for a 14-day quarantine period, during which they are not allowed to leave their homes or hotels" (McKenna, 2020). This move, although infringing on citizens' rights to free will by making it compulsory to download a government application, allowed the Republic of Korea to successfully enforce the arrival quarantine and prevent the introduction of new infections into the country. Furthermore, Korean citizens received notifications on their cellphones whenever they were in close contact with an infected person, advising them to get tested. "While citizens in many Western countries would see this as an outrageous infringement of privacy, the public has accepted it" (McKenna, 2020).

\section{The COVID-19 Pandemic in the United States of America}

"The U.S. has struggled to respond. The Trump administration focused on travel bans to keep the "foreign" virus out rather than on mobilizing public health capacities to detect and respond-a message that aligns with the Trump administration's election-year anti-immigrant and anti-China political frame." (Kavanagh \& Singh, 2020). Even when responding to an unprecedented pandemic, the United States government was preoccupied with politics, re-election, and internal opposition, rather than focusing on taking the necessary measures to prevent the spread of the pandemic. The United States currently has the largest number of COVID-19 cases, at 2,833,552, with 129,408 deaths. This failure to contain the pandemic can be attributed in part to the fragile nature of US federal policy; "successive presidents of both parties threw out the previous administrations' pandemic strategies, only to later realize that such planning was actually important and scramble to replicate it (Morrow \& McMahon, 2020). The White House's health and security unit from the Obama administration was dissolved in 2018 by the Trump administration, only to be replaced by its own partially implemented response strategy (Morrow \& McMahon, 2020)

\section{Failure to Consolidate State Responses}

The US government structure allows each state a degree of autonomy when it comes to running and deciding its affairs, and while this power was vested in them for benevolent reasons, in times of crisis, they can prove to be major drawbacks as the power can be misused for political gain and opposition. During the early stages of the pandemic, the lack of federal control led to states such as Washington and California, imposing lockdowns and social distancing measures as early as March 16, while the mayor of New York City was urging people to "get out on the town" for seemingly economic reasons. (Morrow \& McMahon, 2020). In New York, it took two weeks for the governor and mayor to finally agree to imposing a lockdown. "New York State rapidly became the pandemic's epicentre, with more than 30,000 deaths. California's per capita death rate has been less than one-15th that of New York State; Washington's was about one-10th. While there were other factors at play, including New York's density, epidemiologists agree that the state lost valuable time in the early days of the outbreak that could have saved lives." (Morrow \& McMahon, 2020). This lack of consensus between pandemic response amongst the states could be attributed to the inability of the federal government to assume central management of the response at an early stage due to fundamental, constitutional impediments.

\section{Legal Challenges to Travel Restrictions and Quarantine}

"The United States government lacks the broad authority to impose the sweeping quarantine seen in China, were some 70 million people were confined;" neither the federal nor state governments have the authority to impose wide 
quarantines on large population centres such as entire cities, towns, or even states (The New York Times, 2020). When New York City quickly became the epicentre of the COVID-19 epidemic in the United States, the most the US government could do to prevent New Yorkers from spreading the disease to other parts of the country was to issue a travel advisory. The governor of New York, Andrew Cuomo, stated, "If you start walling off areas all across the country, it would be totally bizarre, counterproductive, anti-American, and anti-social," hinting that any federal effort to lock down New York would be strongly opposed. The Trump administration had initially considered a quarantine of New York, but US law did not clarify whether Trump could ban people from leaving their state, leaving a high chance that such a measure would be challenged in courts (Miller \& Long, 2020). Although US states and local governments possess the powers to impose quarantines in the interest of public health, constitutional protections mandate that the government must prove that a quarantine imposed on a person is the least restrictive method available, and they must have sufficient evidence that the said person was exposed. (Price, 2020). Unfortunately, the power to impose local quarantines/isolation is not vested in the federal government, but rather spread throughout 2,684 different health departments at varying levels of government, thus detracting from a unified, nationwide containment effort as each jurisdiction would be free to make its own decisions (Price, 2020). This delegation of authority can lead to external factors such as economic gain or private sector lobbying influencing local decisions on quarantine and the sacrifice of lives in return for monetary gain. It is clear that the lack of centralization of power and clear constitutional authority for imposing severe restrictions, such as what is present in China and Italy, hampered the United States' efforts to control the spread of COVID-19 in an effective and timely manner.

\section{Conclusion}

The COVID-19 pandemic has affected hundreds of countries with varying systems of government and degrees of power centralization and it is visible from the currently available data that authoritarian governments such as China, and those with high centralization of power such as South Korea, have had better results in controlling the spread of the virus as compared to libertarian, democratic countries with vast power dissemination across varying levels of government such as the United States. The legal, ideological, and social hurdles faced by the United States has hampered the nation's ability to curb the COVID-19 pandemic whilst the virtually unlimited powers of the communist China's central government have allowed it to impose severe restrictions and control the spread of SARS-CoV-2 with minimal loss of life and economic costs.

\section{References}

Miller, H. (2020, February 03). In pictures: China is building two hospitals in less than two weeks to combat coronavirus. Retrieved from https://www.cnbc.com/2020/01/31/pictures-china-buildstwo-hospitals-in-days-to-combat-coronavirus.html

Rapoza, K. (2020, April 27). China Has 'Nationalized' Its N95 Mask Makers. Retrieved from https:/www.forbes.com/sites/kenrapoza/2020/04/26/china-has-nationalized-its-n95-mask-makers/

Anderson RM, Heesterbeek H, Klinkenberg D, Hollingsworth TD. How will country-based mitigation measures influence the course of the COVID-19 epidemic?. Lancet. 2020;395(10228):931-934. doi:10.1016/S0140-

$6736(20) 30567-5$ 
To curb covid-19, China is using its high-tech surveillance tools. (2020, February 29). Retrieved from https://www.economist.com/china/2020/02/29/to-curb-covid-19-china-is-using-its-high-tech-surveillance-tools

Dewan, A., Berlinger, J., \& Marsh, J. (2020, February 08). China threatens harsh punishments for people who disrupt virus control ... including the death penalty. Retrieved from https://edition.cnn.com/asia/livenews/coronavirus-outbreak-02-08-20-intlhnk/h 7e7dfec565c5dc7d3a7570c2138b39da

Shin, Y., Berkowitz, B., \& Kim, M. J. (2020, March 25). How a South Korean church helped fuel the spread of the coronavirus. Retrieved from https://www.washingtonpost.com/graphics/2020/world/coronavirussouth-korea-church/

McKenna, T. (2020, April 20). How South Korea managed to flatten the COVID-19 curve | CBC News. Retrieved from https://www.cbc.ca/news/investigates/south-korea-covid-19-outbreak-record-1.5537631

Kavanagh, M. M., \& Singh, R. (2020). Democracy, Capacity, and Coercion in Pandemic Response-COVID 19 in Comparative Political Perspective. Journal of Health Politics, Policy and Law. doi:10.1215/03616878-8641530

Morrow, A., \& McMahon, T. (2020, June 10). In the U.S., coronavirus is a failure decades in the making. Is there time to do better? Retrieved from https://www.theglobeandmail.com/world/us-politics/article-americas-other-crisis-covid-19-is-a-failure-decades-in-the-making/

Macfarquhar, N. (2020, July 1). Can You Be Forced to Quarantine or to Stay Home? Your Questions, Answered. Retrieved from https://www.nytimes.com/article/coronavirus-quarantine-questions.html

Miller, Z., \& Long, C. (2020, March 28). Trump: No quarantine, but travel advisory for NY, CT and NJ.Retrieved from https://www.ctvnews.ca/health/coronavirus/trump-no-quarantine-but-travel-advisory-for-nyct-and-nj-1.4872590

Price, P. J. (2020, February 16). A Coronavirus Quarantine in America Could Be a Giant Legal Mess.Retrieved from https://www.theatlantic.com/ideas/archive/2020/02/coronavirus-quarantine-america-could-begiant-legal-mess/606595/

Altakarli, N. S. (2020). China's Response to the COVID-19 Outbreak: A Model for Epidemic Preparedness and Management. Dubai Medical Journal, 1-6. doi:10.1159/000508448 